3. From: (Originating organization)

Plant Systems Technical Basis

G. A. Meyer

Retrieval Programs

5. Proj./Prog./Oept./Div.:

Waste Management

8. Originator Remarks:

Second transmittal for approval and release. Draft document review completed and comments incorporated.

11. Receiver Remarks:
6. Cog. Engr.:

D. F. Iwatate

4. Related EOT No.:

$N / A$

7. Purchase Order No.:

$\mathrm{N} / \mathrm{A}$

9. Equip./Component No.:

$\mathrm{N} / \mathrm{A}$

10. System/Bldg./Facility: $\mathrm{N} / \mathrm{A}$

12. Major Assm. Dwg. No.: $N / A$

13. Permit/Permit Application No.: $\mathrm{N} / \mathrm{A}$

14. Required Response Date: $N / A$

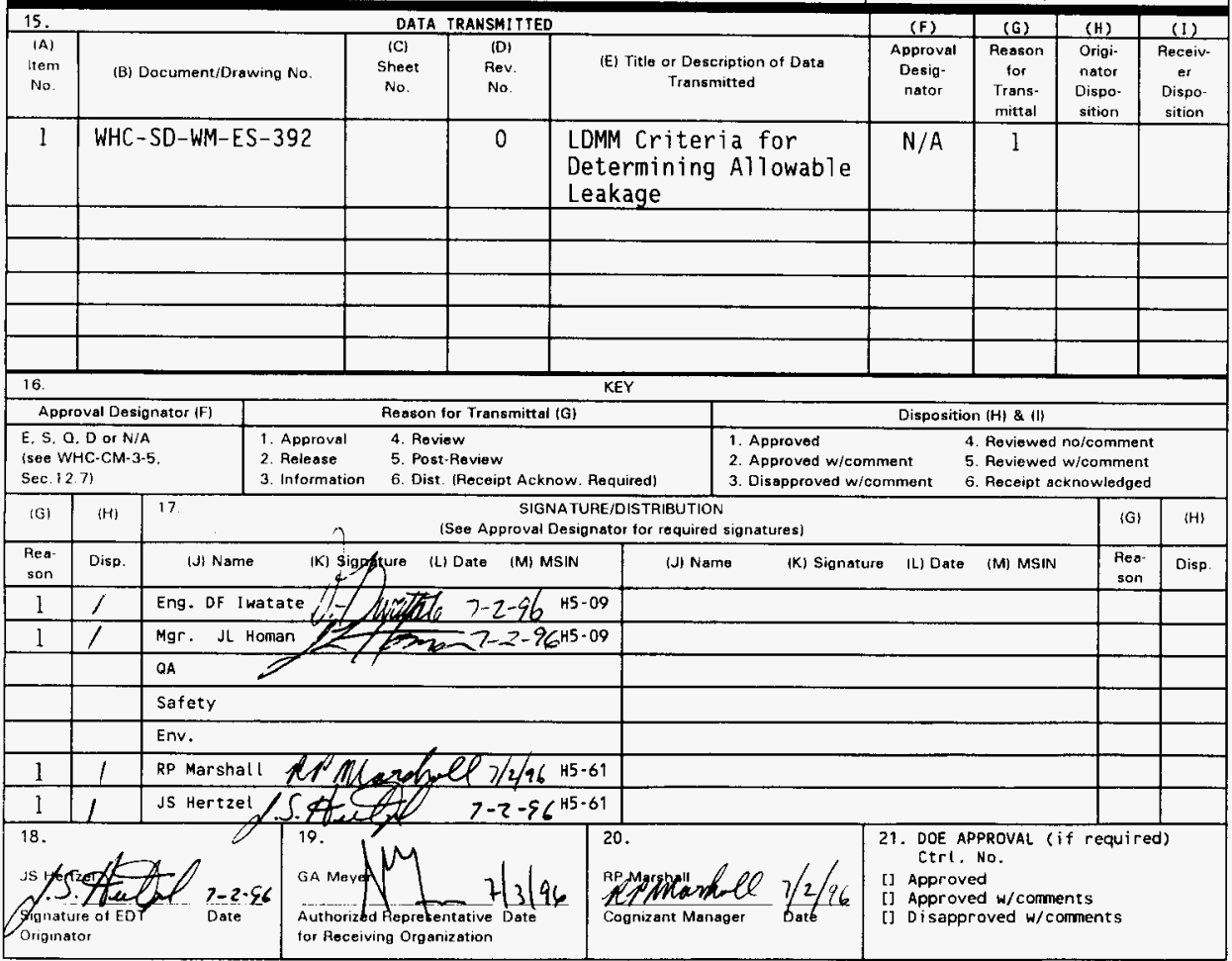

BD-7400-172-2(04/94) GEF097 


\section{Leak Detection, Monitoring, and Mitigation (LDMM) Criteria for Determining Allowable Leakage}

D. F. Iwatate

Westinghouse Hanford Company, Richland, WA 99352

U.S. Department of Energy Contract DE-AC06-87RL10930

EDT/ECN: $606481 \quad$ UC: 721

Org Code: $73530 \quad$ Charge Code: 02046

B\&R Code: EW3130010 Total Pages: 3940

Key Words: Single-She1l Tanks, waste, leak, detection, monitoring, mitigation

Abstract: This document proposes criteria and measures for leak detection, monitoring, and mitigation (of Hanford single-shel1 tanks during waste retrieval by sluicing) to support fulfiliment of TPA Milestone M45-08-T02. This milestone specifies that, "...criteria for determining allowable leakage volumes..." will be presented to Washington State Dept of Ecology for approval. This document presents candidate criteria statements, including summary of issues and recommended resolution.

TRADEMARK DISCLAIMER. Reference herein to any specific commercial product, process, or service by trade name, trademark, manufacturer, or otherwise, does not necessarily constitute or imply its endorsenent, recommendation, or favoring by the United States Government or any agency thereof or its contractors or subcontractors.

Printed in the United States of America. To obtain copies of this document, contact: WHC/BCS Document Control Services, P.O. Box 1970, Mailstop H6-08, Richland WA 99352, Phone (509) 372-2420; Fax (509) 376-4989.
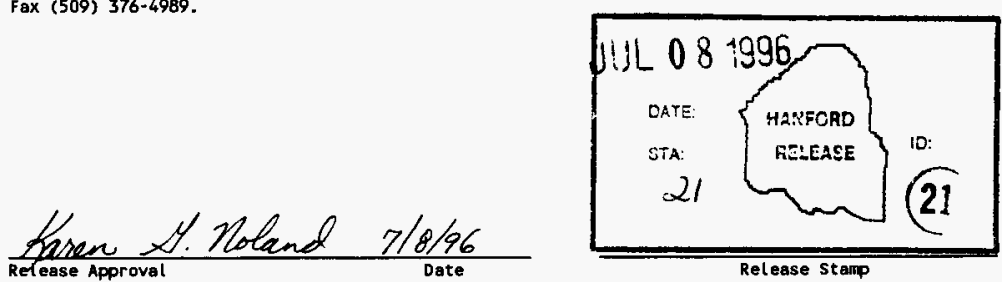

Approved for Public Release 
湴

FOSTER WHEELER ENVIRONMENTAL CORPORATION

\section{LDMM Criteria for Determining Allowable Leakage}

WHC-SD-WM-ES-392, REV. 0

May 24, 1996

Prepared for

Westinghouse Hanford Company

Tank Waste Remediation System

Task 021 of Order No. MGK-SVV-186918

Prepared by

Foster Wheeler Environmental Corporation

1981 Snyder Road, Suite 3

Richland, WA 99352 


\section{ACRONYMS AND ABBREVIATIONS}

COC constituents of concern

DOE U.S. Department of Energy

DST double-shell tank

Ecology Washington State Department of Ecology

EIS Environmental Impact Statement

ERT electrical resistivity tomography

ILCR incremental lifetime cancer risk

LDMM leakage detection, monitoring, and mitigation

MCL Maximum Contaminant Level

MEI maximally exposed individual

RCRA Resource Conservation and Recovery Act

SST single-shell tank

Tri-Party

Agreement Hanford Federal Facility Agreement and Consent Order

TWRS

Tank Waste Remediation System 
WHC-SD-WM-ES-392 REV. 0

This page intentionally left blank. 
WHC-SD-WM-ES-392 REV. 0

TABLE OF CONTENTS

1.0 INTRODUCTION AND BACKGROUND $\ldots \ldots \ldots \ldots \ldots \ldots \ldots \ldots$ 1-1

2.0 SUMMARY OF ALLOWABLE LEAKAGE DETERMINATION STRATEGY $\ldots . \quad 2-1$

2.1 TIER 1: SOIL CAPACITY VALUE $\ldots \ldots \ldots \ldots \ldots \ldots \ldots \ldots \ldots .1$

2.1.1 Fate of Leakage From SSTs . . . . . . . . . . . . 2-2

2.1.2 Calculation of Soil Capacity Value $\ldots \ldots \ldots \ldots \ldots \ldots \ldots . \ldots \ldots 2-2$

2.2 TIER 2: MAXIMUM POTENTIAL LEAKAGE $\ldots \ldots \ldots \ldots \ldots \ldots 2-3$

2.2.1 Calculation of Maximum Potential Leakage . . . . . . . . 2-3

2.3 TIER 3: MINIMUM PRACTICABLE ACHIEVABLE LEAKAGE . . . . . 2-4

3.0 ALLOWABLE LEAKAGE CRITERIA $\ldots \ldots \ldots \ldots \ldots \ldots \ldots$ 3-1

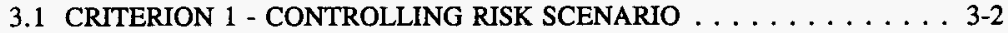

3.1 .1 Importance of Criterion . . . . . . . . . . . . . 3-2

3.1 .2 Criterion Recommendation . . . . . . . . . . . 3-2

3.2 CRITERION 2 - RISK MODELS AND DATA $\ldots \ldots \ldots \ldots \ldots \ldots$ 3-3

3.2 .1 Importance of Criterion . . . . . . . . . . . . 3-3

3.2.2 Criterion Recommendation . . . . . . . . . . . . 3-3

3.3 CRITERION 3 - POINT OF COMPLIANCE $\ldots \ldots \ldots \ldots \ldots \ldots . . \ldots 3$

3.3.1 Importance of Criterion . . . . . . . . . . . . . 3-4

3.3.2 Criterion Recommendation . . . . . . . . . . . 3-4

3.4 CRITERION 4 - PERIOD OF COMPLIANCE $\ldots \ldots \ldots \ldots \ldots \ldots .3-5$

3.4.1 Importance of Criterion . . . . . . . . . . . . 3-5

3.4.2 Criterion Recommendation . . . . . . . . . . . . 3-5

3.5 CRITERION 5 - CONSTITUENTS OF CONCERN . . . . . . . . 3-6

3.5.1 Importance of Criterion . . . . . . . . . . . . 3-6

3.5.2 Criterion Recommendation . . . . . . . . . . . . . 3-6

3.6 CRITERION 6 - VADOSE ZONE FLUX DISTRIBUTION . . . . . . 3-7

3.6.1 Importance of Criterion . . . . . . . . . . . 3-7

3.6 .2 Criterion Recommendation . . . . . . . . . . . . 3-7

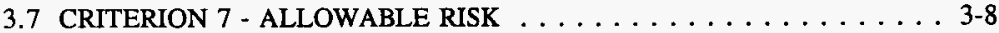

3.7.1 Importance of Criterion . . . . . . . . . . . . 3-8

3.7.2 Criterion Recommendation . . . . . . . . . . . . 3-8

3.8 CRITERION 8 - TANK SOURCES OF RISK . . . . . . . . . . 3-9

3.8.1 Importance of Criterion . . . . . . . . . . . . . 3-9

3.8.2 Criterion Recommendation . . . . . . . . . . . . . . . . 3-9

3.9 CRITERION 9 - LEAKAGE CONCENTRATIONS . . . . . . . 3-10

3.9 .1 Importance of Criterion . . . . . . . . . . . . 3-10

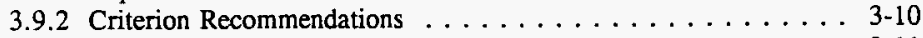

3.10 CRITERION 10 - ACCEPTABLE CLOSURE OPTIONS $\ldots \ldots \ldots$ 3-11

3.10.1 Importance of Criterion . . . . . . . . . . . 3-11

3.10 .2 Criterion Recommendation . . . . . . . . . 3-11 
TABLE OF CONTENTS (cont'd)

3.11 CRITERION 11 - LEAKAGE VOLUMES . . . . . . . . . . . 3-12

3.11 .1 Importance of Criterion . . . . . . . . . . . . . 3-12

3.11 .2 Criterion Recommendations .............. . . 3-12

3.12 CRITERION 12 - ALIGNED WASTE SOURCES ... . . . . . 3 3-13

3.12 .1 Importance of Criterion . . . . . . . . . . . . . . 3-13

3.12 .2 Criterion Recommendation . . . . . . . . . . . . . 3-13

3.13 CRITERION 13 - RISK APPORTIONMENT . . . . . . . . . . . . 3-14

3.13 .1 Importance of Issue $\ldots \ldots \ldots \ldots \ldots \ldots . \ldots \ldots . \ldots \ldots$ 3-14

3.13.2 Criterion Recommendation ................ 3-14

3.14 CRITERION 14 - LEAKAGE DETECTION TECHNOLOGY . . . . . . 3-15

3.14.1 Importance of Criterion . . . . . . . . . . . . . 3-15

3.14.2 Criterion Recommendation ... . . . . . . . . . . . 3-15

3.15 CRITERION 15 - LEAKAGE MITIGATION TECHNOLOGY . . . . . . 3-16

3.15 .1 Importance of Criterion . . . . . . . . . . . . . 3-16

3.15 .2 Criterion Recommendations . . . . . . . . . . . 3-16

3.16 CRITERION 16 - INDIVIDUAL TANK CHARACTERISTICS . . . . 3-17

3.16.1 Importance of Criterion . . . . . . . . . . . . . . . 3-17

3.16 .2 Criterion Recommendation ... . . . . . . . . . . . 3-17

3.17 CRITERION 17 - EXCEEDANCE OF ALLOWABLE LEAKAGE

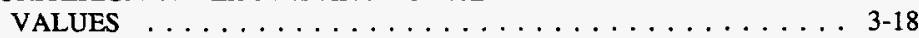

3.17 .1 Importance of Criterion . . . . . . . . . . . . . 3-18

3.17 .2 Criterion Recommendation ............... . . 3-18

3.18 CRITERION 18 - EXCEEDANCE OF LEAKAGE CEILINGS . . . . . 3-19

3.18 .1 Importance of Criterion . . . . . . . . . . . . . . . . 3-19 . . . . . . . . . . . .

3.18 .2 Criterion Recommendation . . . . . . . . . . . . . . 3-19

3.19 CRITERION 19 - ABSOLUTE LIMIT ON ALLOWABLE LEAKAGE . . 3-20

3.19 .1 Importance of Criterion . . . . . . . . . . . . . . . 3-20

3.19.2 Criterion Recommendation . . . . . . . . . . . . . 3-20

4.0 EXAMPLE PROCESS FOR DERIVING ALLOWABLE LEAKAGE VALUES . . . 4-1

4.1 PRELIMINARY ALLOWABLE LEAKAGE VALUES . . . . . . . . . . . . . . . . .

4.2 ADJUSTED ALLOWABLE LEAKAGE VALUES . . . . . . . . . . . . 4-3

5.0 SUMMARY OF CRITERIA RECOMMENDATIONS REQUIRING

APPROVAL .......................... . . . .

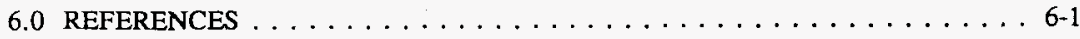

\section{LIST OF TABLES}

3-1 Allowable Leakage Criteria and Associated Issues . . . . . . . . . . . . . . . . . . . . .

4-1 Hypothetical Preliminary Allowable Leakage Criteria . . . . . . . . . . . . . 4-3

5-1 Summary of Criteria Recommendations . . . . . . . . . . . . . . 5-1 


\subsection{INTRODUCTION AND BACKGROUND}

The M-45 series of Hanford Federal Facility Agreement and Consent Order (Tri-Party Agreement) milestones address leakage from single-shell tanks (SSTs) during waste retrieval. Tri-Party Agreement milestone M-45-08-T02 specifies that, "criteria for determining allowable leakage volumes, and acceptable leakage monitoring, detection, and mitigation measures necessary to permit sluicing operations" be approved by the Washington State Department of Ecology (Ecology). To meet this milestone, the U.S. Department of Energy (DOE) and its contractors will (1) develop the background and basis for a criteria decision, (2) propose appropriate criteria and measures for leakage detection, monitoring, and mitigation (LDMM), and (3) establish an agreement with Ecology regarding the issues and recommendations. This document addresses item 2, propose appropriate criteria and measures for LDMM.

The allowable leakage from a single-shell tank during new sluicing operations should be based on relevant regulatory, policy, and technical criteria. These criteria are measures or approaches (to resolve questions/issues) that will provide a basis for making decisions regarding LDMM and allowable leakage during SST waste retrieval. The criteria should be supported by accepted and/or approved enabling assumptions and data. There are significant issues, assumptions, and data related to each criterion. Resolution of issues will require policy decisions or guidance, and improved data in some cases. The following sections identify the larger issues and make recommendations regarding reasonable assumptions and data needs.

Section 2 provides a summary of the LDMM operational strategy and introduces a graded or tiered approach to establish allowable leakage values. Section 3 identifies preliminary criteria and recommendations for resolving issues that may impact the level of allowable leakage. Section 4 gives an example of a proposed process for determining preliminary allowable leakage values for planning purposes and a hypothetical example of how these values would change as tank waste retrieval proceeds. The key criteria and recommendations are summarized in Section 5. 
WHC-SD-WM-ES-392 REV. 0

This page intentionally left blank. 


\subsection{SUMMARY OF ALLOWABLE LEAKAGE DETERMINATION STRATEGY}

Past-practice sluicing has been selected as the method that will be used to remove saltcake and sludge waste from Hanford Site SSTs. Three LDMM concerns during sluicing are (1) determining when a leakage "event" has occurred, (2) ensuring adequate surveillance of existing or new leak plumes, and (3) taking responsible retrieval actions that minimize the potential for leakage to occur. These concerns will be addressed through appropriate operational responses and the use of devices for leakage detection, leakage plume monitoring, and leakage mitigation. Retrieval operations will apply current LDMM measures to maintain leakage at the lowest levels practicable and below allotted leakage ceilings. Establishment of [allowable] operational leakage parameters will be achieved by risk-based decision making applied to a set of criteria. Allowable leakage criteria have been identified and prioritized for consideration within the decision-making process. All of the criteria fall into a sequence or path to establishing the allowable leakage volume. This path consists of the following steps:

- Enabling assumptions are made

- $\quad$ Required data are obtained and reviewed

- Issues are addressed to a "concluding point"

- Decisions are made

- Criteria are developed to a clear statement and are closed

- The criteria are sequentially addressed, resulting in preliminary allowable leakage volumes

- The assumptions and data are reviewed and the allowable leakage volumes revised as waste retrieval proceeds.

Three major tiers have been recommended to establish allowable leakage values: (1) site-specific soil moisture retention capacity, (2) maximum potential leakage due to retrieval by sluicing, and (3) leakage constraints that will be imposed upon operations during actual retrieval/sluicing activities. This three-tiered approach to defining leakage boundaries is discussed in the following sections.

\subsection{TIER 1: SOIL CAPACITY VALUE}

At Tier 1 a combination of historical and theoretical data will be evaluated and compared with vadose zone modeling data to produce a bounding value for the retention capacity of leakage in the soil beneath a target tank and/or tank farm. This value represents the highest volume of liquid waste (maximum tolerable leakage) that could be expected to penetrate into the surrounding soil to a depth that would not render impractical the 
remediation of unacceptable contamination resulting from the leakage. The modeling applied for this decision would include consideration of existing leakage plumes, and local soil and hydrology characteristics. This volume provides the first level of maximum tolerable leakage volume. Leakage of this magnitude would have a high potential to impact the groundwater within several decades if not remediated, and would substantially contaminate the soil in and around the target tank.

\subsubsection{Fate of Leakage From SSTs}

Leakage that occurs from SSTs will pass through the pore spaces between soil particles and migrate laterally and downward due to the force of gravity and the stratigraphic, anisotropic, and other physical characteristics of the soils. The resulting plumes will generally be ellipsoidal and elongated in the horizontal direction. A newly created plume will spread in the soil rather quickly when leakage first occurs. Its growth will diminish when the water has spread to the point that the plume water becomes restrained in the soil capillaries. The plume will then migrate very slowly toward the water table. Downward plume migration rates depend on (1) recharge (the amount of precipitation that infiltrates the soil after subtracting evaporation and transpiration by plant roots) and (2) the physical characteristics of the soil that control the ability of the soil to retain water. These rates can vary from about 1 in. per year to more than $35 \mathrm{ft}$ per year for the different water contents and soil types found beneath the Hanford Site 200 Areas tank farms.

An example of the fate of leakage from an SST is Tank 241-T-106, which leaked $115,000 \mathrm{gal}$ in 1973. This is the largest tank leakage experienced to date at the Hanford Site. The leakage from this tank formed a generally static plume about $180 \mathrm{ft}$ long, $160 \mathrm{ft}$ wide, and 70 to $90 \mathrm{ft}$ deep. Leakage investigations in 1979 indicated that the leakage was located at least $95 \mathrm{ft}$ above the water table. Later monitoring in 1993 and 1994 indicated that the base of the plume was about $75 \mathrm{ft}$ above the water table. These results cannot be directly compared because they are based on monitoring of different radionuclides; however, they do provide support to the concept of a relatively large soil leakage retention capacity and a relatively slow migration rate.

\subsubsection{Calculation of Soil Capacity Value}

Tank razing and soil excavation are the assumed remedial actions that would be taken for mitigating leakage when the leakage ceiling established to enable the most cost-effective closure approach is exceeded. There are practical limits to these actions, based on worker risk and cost, number of tanks razed, soil volume excavated, and depth of soil excavation. The moisture retention capacity of the soil and the leakage plume's rate of downward movement are dependent on the properties of the soil. The allowable time period from the original leak until mitigative actions are completed must be established.

Based on a cursory review of data on site soil beneath the Hanford Grout Facility, it is estimated that the soil can hold an additional $8 \mathrm{vol} \%$ or more of moisture before its matric 
potential would increase to a level above $-10 \mathrm{~cm}$ water. Water will freely drain in soil at a matric potential of about zero or higher. The base of many of the SSTs are approximately $150 \mathrm{ft}$ above the aquifer. If the plume cross-section is assumed to be equal to the tank footprint and to extend halfway to the aquifer, the soil leakage capacity value is $200,000 \mathrm{gal}$ or larger, based on a minimum moisture increase of $8 \mathrm{vol} \%$. This is in rough agreement with the Tank 241-T-106 leakage data described in Section 2.1.1. This value is compared with the maximum potential leakage volume (Tier 2) described in Section 2.2.

\subsection{TIER 2: MAXIMUM POTENTIAL LEAKAGE}

A comparison between the volume of a maximum potential leakage that could occur from a target tank due to a retrieval action such as sluicing (Tier 2), and the Tier 1 soil capacity value should be made. The Tier 2 maximum potential leakage would occur if the leakage detection and response system failed to detect and mitigate catastrophic leakage that occurred near the beginning of retrieval operations. The difference between Tier 1 and Tier 2 leakage values provides a measure of the effectiveness of the soil beneath the tank to ensure interim protection of the groundwater, if the maximum leakage were to occur. Even though the potential for the occurrence of maximum volume leakage (Tier 2) is very small, there is no way to guarantee against it. This is due to the lack of significant and absolute control over leakage once it occurs, and the inaccuracy with which leakage can be detected using currently available technology. Therefore, the risks associated with this maximum volume of leakage must be judged "acceptable" before proceeding with sluicing.

\subsubsection{Calculation of Maximum Potential Leakage}

The SST slurry pump and the double-shell tank (DST) sluice pump flow rates will be matched during sluicing to continually maintain a head of liquid over the slurry pump intake. A major leak in the SST in this case would lower the head in the slurry pump and cause the pump to cavitate, signalling potential leakage to the operators. The sluicing system would be shut down with no further liquid added to the SST. The volume of liquid that could leak if a catastrophic leak were to occur at this point is the liquid head at the pump intake plus the drainable liquid contained in the waste. The maximum leakage would occur if the catastrophic leak happened near the beginning of the retrieval operation when the waste volume is at a maximum and when the pump intake is submerged in liquid.

Two cases of maximum potential leakage were evaluated based on data from the Waste Tank Summary Report for the Month Ending October 31, 1995 (Hanlon 1995). These include an upper bounding case and an average case. The upper bounding case is a tank nearly full of saltcake waste (i.e., Tank 241-A-101, which contains $950,000 \mathrm{gal}$ of saltcake). Much of the liquid held in the saltcake waste can be assumed to drain, whereas sludge waste has small particle sizes and will tend to hold the interstitial liquid tightly (i.e., it has a high capillarity). The average SST contains $156,000 \mathrm{gal}$ of saltcake waste and 79,000 gal of sludge waste. 
A reasonable assumption is that the retrieval system is operated to maintain a $2-\mathrm{ft}$ head of liquid above the SST slurry pump intake. This equates to $66,000 \mathrm{gal}$ of liquid in a 75-ft diameter tank. The volume of drainable liquid for the Tank 241-A-101 upper bounding case is given in Hanlon (1995). The ratios of drainable liquid to total waste for saltcake and sludge waste can be derived from Tank 241-A-101 data in Hanlon (1995). Applying these ratios to the average case and adding the 66,000 gal from the assumed liquid head gives the following result. The potential upper bounding case leakage is provided for comparison.

Average Case

Upper Bounding Case (Tank 241-A-101)
$140,000 \mathrm{gal}$ $480,000 \mathrm{gal}$.

\subsection{TIER 3: MINIMUM PRACTICABLE ACHIEVABLE LEAKAGE}

The Tier 1 analysis established the maximum volumes of leakage allowable to ensure interim protection of the groundwater. In most cases the maximum potential leakage determined in the Tier 2 analyses will be less than Tier 1 levels. Lower levels of allowable leakage (Tier 3) will be imposed to create an even greater degree of protection. The Tier 3 levels serve as constraints within which retrieval actions can proceed. Tier 3 leakage limits will be imposed as a means of optimizing potential for cost-effective and compliant closure of the tanks following sluicing. Actions that will help attain these limits and the goal of minimum practicable achievable leakage include ordering the tanks for retrieval based on the potential leakage risks, availing a range of pre-approved operational leakage response actions, enhancing design of the sluicing equipment, modifying current operations procedures and decision-making plans, and making maximum use of currently available technologies and methods.

The allowable leakage criteria associated with the three-tiered approach to defining leakage boundaries are discussed in greater detail in Section 3. 


\subsection{ALLOWABLE LEAKAGE CRITERIA}

The allowable leakage from an SST during new sluicing operations should be based on relevant regulatory, policy, and technical/operational criteria. The criteria should be supported by accepted and/or approved enabling assumptions and data. There are significant issues associated with the criteria and the assumptions and data. Resolution of issues will require policy decisions, guidance, and improved data. This will lead to clarification and closure of the criteria. This section identifies 19 important allowable leakage criteria and includes recommendations for the quantification and justification of each. A summary of the leakage criteria and related issues is provided in Table 3-1.

Table 3-1. Allowable Leakage Criteria and Associated Issues.

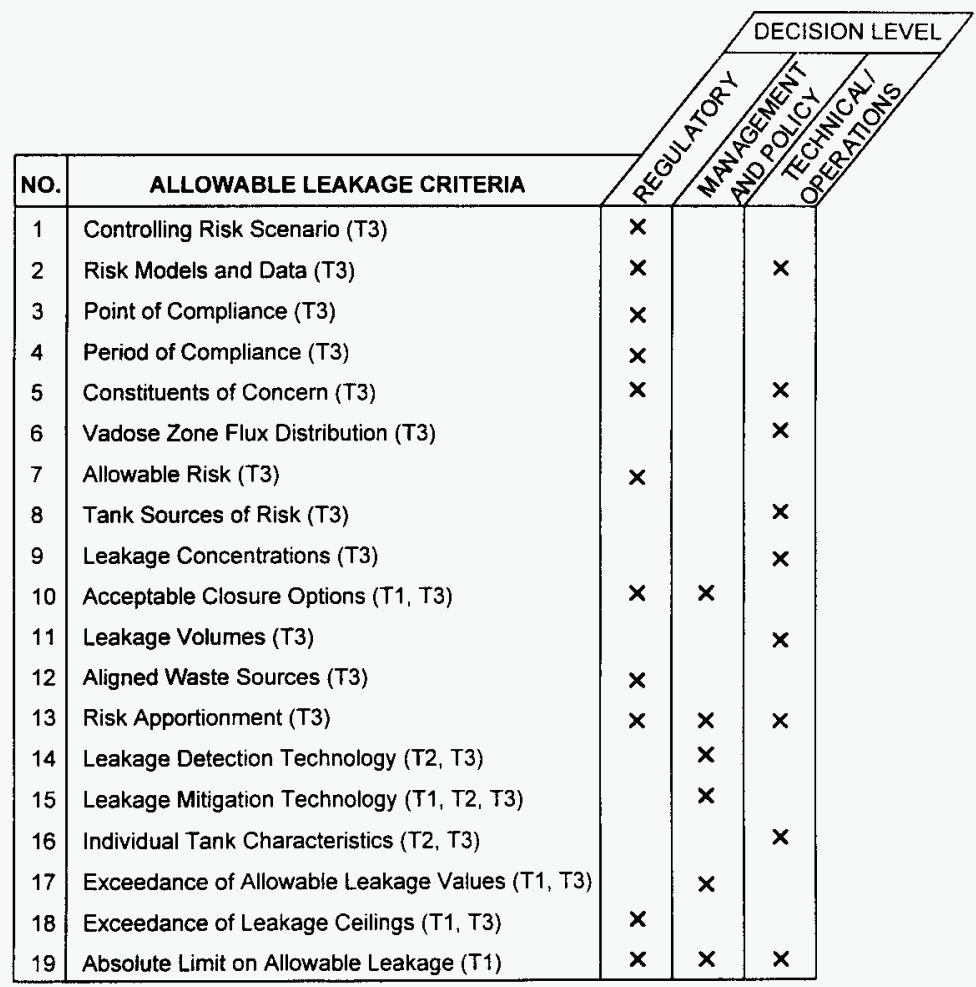

$\mathrm{T} 1=$ Applicable to Tier $1 \quad \mathrm{~T} 2=$ Applicable to Tier 2 T3 = Applicable to Tier 3 
WHC-SD-WM-ES-392 REV. 0

\subsection{CRITERION 1 - CONTROLLING RISK SCENARIO}

Establish the controlling risk scenario to determine how much leakage is harmful.

\subsubsection{Importance of Criterion}

The controlling risk scenario must be established to provide the basis for making defensible risk-based decisions regarding potential impacts of waste leakage. Various risk scenarios are evaluated under the National Environmental Policy Act, the Comprehensive Environmental Response, Compensation, and Liability Act, the Resource Conservation and Recovery Act (RCRA), and DOE guidance to support remedial action decision making. Common risk scenarios include those that adversely impact worker health and safety, degrade short- and long-term public health, and damage the ecology. The primary objective of most cleanup actions is to ensure long-term protection of human health. Most long-term risk analyses focus on the impacts to a maximally exposed individual (MEI) who uses contaminated groundwater or surface water. The draft Tank Waste Remediation System (TWRS) Environmental Impact Statement (EIS) focused its evaluation on the health risk to a maximally exposed onsite farmer who uses contaminated groundwater under the Hanford Site. Regulatory limits exist to protect the groundwater and users of groundwater (e.g., Maximum Contaminant Levels [MCLs]). The draft TWRS-EIS also evaluated an intruder risk scenario that showed significantly higher risks to the intruder; however, no regulatory limit is known to exist for the protection of intruders. The existence of regulatory limits for protection of groundwater supports selection of the onsite MEI farmer using contaminated Hanford groundwater as the controlling risk scenario.

\subsubsection{Criterion Recommendation}

The controlling risk scenario for SST leakage should be exposure of the MEI (onsite farmer) to contaminated drinking water from a well and to farm products grown with the same well water. The same risk exposure pathways and parameters used in the draft TWRSEIS should be used for preliminary evaluations of allowable leakage. This will enhance comparability to the TWRS analyses and promote better understanding and approval by the sponsoring agencies (Ecology and DOE). The intruder scenario should not be selected as the controlling risk scenario because no regulatory limits exist for protecting intruders. 


\subsection{CRITERION 2 - RISK MODELS AND DATA}

Establish the mathematical models, boundary conditions, and input data to be used to simulate the controlling risk scenario.

\subsubsection{Importance of Criterion}

It is necessary to establish a consistent, approved approach for using specific models, data, and boundary conditions to increase acceptance of the modeling results. Large differences in calculated risks can result when different contaminant fate and transport models and assumptions are used. The draft TWRS-EIS used (1) a congruent dissolution model to simulate release of contaminants from the tanks to the vadose zone, (2) a onedimensional advective-dispersion (no diffusion) model to simulate transport of contaminants through the vadose zone, and (3) a one-dimensional advective-dispersion model to simulate transfer of contaminants in the aquifer to the Columbia River. Adjacent tank farms were grouped into source areas in the draft TWRS-EIS. The contaminant flux from each source area was assumed to be uniformly released into a vadose-zone cell with surface dimensions of 0.6 by $0.6 \mathrm{mi}$. The flux entering the groundwater was assumed to be dispersed uniformly and vertically in the groundwater to a depth of $20 \mathrm{ft}$. The resulting groundwater plume was assumed to disperse laterally and horizontally within the constraints of established Hanford Site aquifer boundary conditions. This model is appropriate for far-field projections of risk to the MEI (onsite farmer).

Other refinements, such as (1) including past leakage in the analysis, (2) including a diffusion algorithm in the vadose zone transport model, (3) using solubility-limited release algorithms, and (4) reducing the dimensions of the vadose zone flow cells to correspond to the footprints of individual tank farms have been used in previous modeling efforts.

\subsubsection{Criterion Recommendation}

Simple one-dimensional release algorithms and transport models should be used for preliminary evaluations of allowable leakage. The same or equivalent algorithms and models used in the draft TWRS-EIS should be employed. Boundary conditions and input data should be identical. Future refinements to models and data should be clearly described and rationale for the changes should be provided. A consistent modeling approach will facilitate comparison of results and enhance defensibility of allowable leakage analyses. 


\subsection{CRITERION 3 - POINT OF COMPLIANCE}

Establish the point of compliance following closure of a tank farm.

\subsubsection{Importance of Criterion}

The point of compliance for a closed waste site is defined in a RCRA closure plan and is usually near the boundary of the waste site. Future Hanford land-use planning efforts may result in establishing a long-term waste disposal site or exclusion area that encompasses both the 200 East and 200 West Areas. The boundaries of the long-term waste site may be a mile or more downgradient from the nearest tank. Groundwater plumes generally increase in width and depth as a function of distance from the contributing waste sources. The increasing plume size is primarily caused by advective dispersion, and results in diluting the contaminant concentrations in the plume. Lower concentrations in the plume equate to lower risk. Thus, the nearer the tank farm, the higher the risk. Assumptions should be made about possible locations of boundaries and compliance points to estimate potential groundwater concentrations of constituents of concem (COCs) and associated risks.

\subsubsection{Criterion Recommendation}

The risk impacts at several potential compliance points should be evaluated to establish the sensitivity of waste site boundary locations. The risk impacts associated with residual waste in the tanks following sluicing and other significant sources such as leakage, should be added to determine cumulative risk. The cumulative risk should be compared to potential risk threshold(s) in the closure plan(s) to determine if compliance can be achieved. These risk analyses will demonstrate the relationship between compliance points and retrieval actions that impact the amount of residual tank waste and amount of leakage (and associated risk) that may occur. 


\subsection{CRITERION 4 - PERIOD OF COMPLIANCE}

Establish the period of time over which compliance must be assured.

\subsubsection{Importance of Criterion}

The COCs in Hanford Site tanks pose different risks due to differing toxicities and mobilities. Certain COCs move with the speed of water because they do not chemically sorb onto soil. Other COCs sorb to varying degrees. If a Hanford Barrier is used over tank farms as part of the closure plan, the barrier will significantly restrict water recharge. Precipitation that penetrates the barrier will not reach the water table for thousands of years. Thus, only the most mobile COCs will reach the groundwater within the 10,000 -year period of regulatory interest. If the Hanford Barrier limits recharge to less than $0.05 \mathrm{~cm} / \mathrm{yr}$, the peak flux of contaminated water to the water table may be delayed to a time after 10,000 years. For all practical purposes, the delay is not dependent on the amount of residual waste in the tanks, nor on the amount of leakage that has occurred. In theory, the Hanford Barrier can eliminate all risks to the MEI within the 10,000 year timeframe, regardless of whether waste removal actions have been taken.

\subsubsection{Criterion Recommendation}

The Hanford Barrier is a key element of the overall strategy for remediating tank farms and its effectiveness must be evaluated. Physical evidence and continuing studies may show that the barrier can limit recharge to less than $0.05 \mathrm{~cm} / \mathrm{yr}$ for more than 10,000 years, assuming barrier maintenance will be performed over that time period as necessary to ensure effective performance. The impacts to risk and compliance for this case should be evaluated over a period that captures the peak risks associated with mobile COCs. This approach is justified if future land-use decisions result in creating a secure, long-term waste disposal area that encompasses the 200 Areas. The assumption is that a secure waste disposal area would be guarded against human intrusion and maintained for as long as the disposal area is considered a threat to human health. Thus, the period of compliance should be 10,000 years, but longer if required to capture peak $\mathrm{COC}$ groundwater concentrations. 


\subsection{CRITERION 5 - CONSTITUENTS OF CONCERN}

Determine the components of SST waste that should be considered COCs.

\subsubsection{Importance of Criterion}

Risk analyses performed at the Hanford Site repeatedly identify the same COCs when the Hanford Barrier is employed and when the period of compliance is less than 50,000 years. The identified COCs are mobile and nonsorbing, and include ${ }^{99} \mathrm{Tc},{ }^{129} \mathrm{I},{ }^{14} \mathrm{C}$, uranium, and nitrate (including nitrite). These COCs typically contribute to greater than $95 \%$ of the cumulative carcinogenic and noncarcinogenic risks.

\subsubsection{Criterion Recommendation}

The recommended COCs are ${ }^{99} \mathrm{Tc},{ }^{129} \mathrm{I},{ }^{14} \mathrm{C}$, uranium, and nitrate. Analyzing only the most significant contributors to risk reduces cost without compromising defensibility of the analysis. 


\subsection{CRITERION 6 - VADOSE ZONE FLUX DISTRIBUTION}

Establish whether the flux of COCs released into the vadose zone from tank farm groupings should be assumed uniformly distributed within a 0.6- by 0.6-mi cell as in the draft TWRS-EIS, or be assumed as released from individual tank farms into cells approximately equal to the footprints of the individual farms.

\subsubsection{Importance of Criterion}

The radius of influence of a well sufficient to meet the drinking water and irrigation needs of a residential farm is about the width of a typical tank farm footprint (e.g., approximately $400 \mathrm{ft}$ ). Thus, if the point of compliance is near the farm, the well can theoretically capture the entire COC flux as it enters the groundwater. The cells evaluated in the draft TWRS-EIS are about eight times the width of a tank farm. Each tank farm cell in the draft TWRS-EIS contains two or more tank farms. Therefore, the draft TWRS-EIS approach will yield lower risk results by up to a factor of four when the point of compliance is near the tank farm. At distances of several miles, the individual plumes will converge and mix due to the effects of advective dispersion. The draft TWRS-EIS approach yields the most defensible risk values when the point of compliance is a substantial distance from the tank farms.

\subsubsection{Criterion Recommendation}

A vadose zone modeling approach should be selected that is technically consistent with assumed point(s) of compliance. Several points of compliance should be evaluated pending definition of the boundaries of a future waste disposal zone(s) that includes the tank farms. An appropriate modeling approach is warranted for near-field points of compliance. 
WHC-SD-WM-ES-392 REV. 0

\subsection{CRITERION 7 - ALLOWABLE RISK}

Establish the allowable risk to the MEI (onsite farmer).

\subsubsection{Importance of Criterion}

Drinking water typically is the primary source of risk to the MEI. The generally accepted upper limits of risks following cleanup of waste sites are an incremental lifetime cancer risk (ILCR) of $10^{-4}$ and a hazard index of 1.0. Washington State's Model Toxic Control Act sets an upper limit of $10^{-5}$ (ILCR) for Level B cleanups. The limit of $4 \mathrm{mrem} / \mathrm{y}$ for consumption of drinking water containing radionuclides is equivalent to an ILCR of $1.2 \mathrm{x}$ $10^{-4}$.

The preferred alternative identified in the draft TWRS-EIS yields a peak risk of $3 \times 10^{-4}$. Thus, the combined risk impacts of the two sources analyzed in the draft TWRSEIS, residual tank waste following retrieval and the $4,000 \mathrm{gal}$ assumed to have leaked from each tank, exceed all regulatory cleanup limits. Previous work performed by Foster Wheeler Environmental indicates that the risks associated with leakage of this magnitude are relatively small in comparison to the risks associated with $1 \%$ residual waste in the tanks. Therefore, the risks associated with the residual waste in the tanks alone are only somewhat less than $3 \times 10^{-4}$. Thus, no leakage from tanks can be allowed unless regulatory limits are raised, unless alternate modeling assumptions are made, unless the level of residual waste in the tanks is reduced, or unless a decision is made that the tanks should be razed and contaminated soil and debris removed.

\subsubsection{Criterion Recommendation}

The effects of alternate modeling assumptions and greater than $99 \%$ cleanup effectiveness should be evaluated against cleanup limits of $10^{-4}$ and $10^{-5} \mathrm{ILCR}$, and a hazard index of 1.0. This evaluation is needed to define conditions that would allow for leakage within acceptable risk constraints, and permit cost-effective closure using backfilling and the Hanford Barrier. 


\subsection{CRITERION 8 - TANK SOURCES OF RISK}

Establish the risk impacts of other sources, e.g., past leakage into the ground and into tank concrete, that should be considered in addition to the risk impacts of residual tank waste and new leakage.

\subsubsection{Importance of Criterion}

Consideration of the risks associated with past leakage may be important for establishing allowable leakage thresholds where high leakage or high-risk leakage has occurred in the past, e.g., in T Tank Farm. Neither past leakage nor contaminated concrete was specifically addressed in the draft TWRS-EIS, although it may have been assumed that these sources are included in the $1 \%$ residual waste source following retrieval operations. The combined effect of these two sources on risk is smaller than the effect of $1 \%$ residual waste remaining in the tanks.

\subsubsection{Criterion Recommendation}

The cumulative risk impacts of all tank sources should be considered, especially if alternate modeling assumptions do not significantly reduce apparent risk and/or if relief in regulatory risk limits cannot be considered or granted at this time. This outcome would drive the need to achieve greater retrieval effectiveness (e.g., $0.1 \%$ residual waste in the tanks). The relative contribution of past leakage into the ground and into concrete would then become significant. 


\subsection{CRITERION 9 - LEAKAGE CONCENTRATIONS}

Determine the methods that should be used to estimate the concentrations of COCs in leakage and the residual tank waste.

\subsubsection{Importance of Criterion}

The concentrations of soluble COCs in the tank liquid, especially ${ }^{99} \mathrm{Tc}$, should be better estimated to determine the risks due to tank leakage and residual tank waste. There is evidence that ${ }^{99} \mathrm{Tc}$, the primary contributor to carcinogenic risk, concentrates in the interstitial liquid that occupies the pore spaces between sludge particles. When an increased hydraulic head of standing sluicing liquid exists in a tank, interstitial liquid may preferentially be driven from the tank through leaks in the tank steel. Improved sluicing methods that would minimize such leakage are under consideration. These methods involve sluicing in the core area of the tank waste in order to retain a layer of waste over holes that may exist in the wall of the tank. When the protective layer of saltcake or sludge on the wall is subsequently removed by sluicing, the concentrations of ${ }^{99} \mathrm{Tc}$ and the other soluble $\mathrm{COCs}$ in the sluicing liquid would be in approximate proportion to their average compositions in the tank.

A small sludge heel is likely to remain when sluicing a tank is completed. The heel material in some tanks has agglomerated and thus, probably has a smaller pore volume than sludge that has not agglomerated. A smaller pore volume would yield a lower fraction of interstitial liquid containing soluble ${ }^{9 \%} \mathrm{Tc}$ and other COCs. However, the sludge particles may contain higher relative amounts of uranium and associated COCs if relatively large particles of undissolved fuel were transferred to the tank. Little information exists on the concentrations of COCs in heels relative to their concentrations in sludge that exists above it.

\subsubsection{Criterion Recommendations}

Average relative concentrations of COCs in sluicing liquid and in sludge should be used until better data are obtained through tank characterization efforts. Concentrations of ${ }^{99} \mathrm{Tc}$ and other COCs proportioned to the saturated concentration of nitrate in interstitial liquid should be used for estimating leakage risks. This approach represents a balance between the higher relative concentrations of ${ }^{99} \mathrm{Tc}$ observed in interstitial liquid and the below-saturated conditions that will probably exist in sluicing waters at the time tank holes are exposed. 
WHC-SD-WM-ES-392 REV. 0

\subsection{CRITERION 10 - ACCEPTABLE CLOSURE OPTIONS}

Identify and establish the acceptability of closure options.

\subsubsection{Importance of Criterion}

There are two basic options for closing tank farms following retrieval of tank wastes: (1) fill the tanks with gravel or grout and cover with a Hanford Barrier (Option 1) or (2) raze the tanks, and retrieve and decontaminate tank debris and contaminated soil (Option 2). Foster Wheeler evaluated in situ washing of contaminated soil as a third option (Option 3), but concluded that the technology would be relatively ineffective and costly. Option 1 is preferred for Hanford Site Tank closure because it involves proven and relatively safe technology. Option 2 is feasible, but is likely to be very expensive pose high worker risks.

\subsubsection{Criterion Recommendation}

Option 1, filling the tanks following sluicing and covering with a Hanford Barrier, is the preferred option due to its relatively low cost, low risk to workers, and use of simple, easily implemented technology. Sluicing can probably be augmented with other tank waste retrieval technologies, such as robotic excavation, as necessary to achieve final cleanup objectives and allow implementation of Option 1 as a compliant alternative. Option 2 should be avoided, wherever possible, by employing optimized sluicing and other effective means to retrieve tank waste and limit leakage. Options 2 or 3 should be exercised only if no other cost-effective supporting technology exists to retrieve waste and limit leakage to levels that would ensure compliance using Option 1. Planning for Options 2 or 3 may be necessary if compliance limits are restrictive and if limits cannot be met with Option 1. 
WHC-SD-WM-ES-392 REV. 0

\subsection{CRITERION 11 - LEAKAGE VOLUMES}

Establish the best method for quantifying the volumes of past and future leakage.

\subsubsection{Importance of Criterion}

Past and future leakage are two contributors to cumulative risk. The volumes of leakage are multiplied by the associated concentrations of COCs in the leakage to establish the source terms used for risk modeling. Hanlon 1995 reports 67 tanks have leaked a total of 600,000 to 900,000 gal of liquid waste during past sluicing and waste storage periods.

The amount of new leakage expected during new sluicing operations has been estimated at between 4,000 and 40,000 gal per leaking tank. Past leakage volumes averaged 11,000 gal per leaking tank. Foster Wheeler assumed that $42 \%$ of all tanks would leak, averaging 40,000 gal apiece during new sluicing operations. These assumptions were based on historical tank failure rates and an estimate of potential leakage from Tank 241-C-106 provided by Westinghouse Hanford Company. Average new leakage of 4,000 gal was assumed for each of the tanks in the draft TWRS-EIS. The assumptions made in the draft TWRS-EIS would result in a factor of four lower overall new leakage, compared to the Foster Wheeler analysis. However, most of the cumulative risk is attributable to the $1 \%$ residual tank waste. Thus, the overall effects of the different leakage assumptions are relatively small. However, the overall effects would be substantial if the residual waste goal were reduced to $0.1 \%$.

\subsubsection{Criterion Recommendations}

Actual leakage volumes during sluicing are expected to vary over a fairly wide range depending on tank conditions and the methods of leak detection and mitigation technologies employed. Improved sluicing techniques (i.e., sluicing the core area of the tank first to retain a layer of waste over holes that may exist in the tank wall) should reduce the potential for and quantity of leakage. This benefit may be offset by the effects of tank aging, which may increase rates of leakage due to creation of cracks and holes caused by tank settling and corrosion.

Longer sluicing durations than in the past may also be required due to the presence of thick saltcake layers and the increased potential for agglomeration of sludge particles, both of which would increase the difficulty of sluicing. An increased sluicing time equates to a longer hydraulic head time. The volume of leakage is directly proportional to both the magnitude of head and the time period of applying the head above a leak. Pending a more rigorous analysis, the average leakage from tanks in the past $(11,000 \mathrm{gal})$ is preliminarily recommended for each tank assumed to leak during new sluicing operations. If reexamination of historical tank failure rates, conditions of individual tanks, and current sluicing schedules continues to support the 11,000 gal leakage volume and the $42 \%$ leakage frequency used by Foster Wheeler, then the average SST leakage would be $4,600 \mathrm{gal}$. This is similar to the value used in the draft TWRS-EIS. 


\subsection{CRITERION 12 - ALIGNED WASTE SOURCES}

Establish whether the impacts of upgradient and downgradient groundwater contamination should be included in risk estimates.

\subsubsection{Importance of Criterion}

Two or more tank farms and other types of waste sites often will be aligned with future groundwater flow directions. The maximally exposed onsite farmer will be subjected to risks from overlapping plumes produced by aligned sources. Appropriate limits for protecting the health of the farmer from the cumulative effects of overlapping plumes need to be defined.

\subsubsection{Criterion Recommendation}

Cumulative risks from all aligned sources should be less than $1.2 \times 10^{-4}$ ILCR through the drinking water pathway (equivalent to $4 \mathrm{mrem} / \mathrm{y}$ ) and less than 1.0 hazard index (including not exceeding the MCL for nitrate). These values are based on regulatory limits for protecting drinking water. 
WHC-SD-WM-ES-392 REV. 0

\subsection{CRITERION 13 - RISK APPORTIONMENT}

Determine the apportionment of allowable cumulative risk among the contributing sources when two or more plumes will overlap.

\subsubsection{Importance of Issue}

Without careful planning and analysis, a potential exists for conducting cleanup actions that are not cost-effective. It may be cheaper, for example, to retrieve extra tank waste than to prevent leakage of equivalent risk, or vice versa. Also, two waste sources, one with and one without the Hanford Barrier, are unlikely to produce significantly overlapping plumes, even when they are aligned. In this event, the period of groundwater contamination in the no-barrier case would be completed well before the first contamination occurs in the barrier case.

\subsubsection{Criterion Recommendation}

If safe groundwater conditions can be assured, the mobile COCs in low-risk sites such as certain cribs and trenches should be allowed to be flushed naturally to the groundwater at the higher recharge rates that occur when no closure barrier is used. This approach avoids the costs of Hanford Barriers for some of the waste sources and creates more flexibility for accommodating the risks associated with aligned sources. The levels of risk reduction required for each of the remaining aligned sources should be based on the alternative that provides for the most cost-effective remediation and closure of all of the aligned sources as a system. Costs in the cost-effectiveness calculation should include all life-cycle costs. Effectiveness should be based primarily on cleanup effectiveness but should be tempered with consideration of worker safety and technical feasibility. Incremental cost-effectiveness analyses should be made to determine if later stages of cleanup action are worthwhile.

Thus, evaluating the aligned sources as a system is recommended to enable definition of the appropriate remedial actions and residual risks for each source. Several iterations may be necessary to identify the most cost-effective cleanup actions that are expected to yield cumulative risks that are in compliance with closure plan limits. 
WHC-SD-WM-ES-392 REV. 0

\subsection{CRITERION 14 - LEAKAGE DETECTION TECHNOLOGY}

Determine the impact of leakage detection and response technology on reducing the amount of new leakage that may occur during sluicing.

\subsubsection{Importance of Criterion}

Currently available leakage detection technology consists of sensitive liquid level measuring devices, flow meters, and visual estimates of remaining solid waste in the tank at various intervals during the tank sluicing cycle. Foster Wheeler estimated the sensitivity of leakage detection by this method at between 6,000 and 20,000 gal after establishing the base sluicing conditions. The establishment of base conditions includes adding sufficient water to replace liquid removed by previous salt well pumping and immerse the intake of the new slurry pump. On average, an addition of about $140,000 \mathrm{gal}$ of water may be required to establish these base conditions before initiating sluicing. Detection of leakage with currently available technology is not possible when base conditions are being established. A potentially promising leakage detection alternative, electric resistance tomography (ERT) may be capable of detecting a 1,000- to 8,000 -gal leak during sluicing as well as during establishment of base conditions. However, the ERT technology is not proven at this time.

After detection of a leak by any method, leakage will continue until the drainable liquid level is pumped down to a level below the level of the leak. Salt well pumping may be required to augment the sluice liquid recovery pump when a leak is suspected on the bottom of a tank or low on the tank's wall. The time required to draw down the drainable liquid level in a tank may be days or weeks depending on the permeability of the waste. A one-day response time for draining a tank may result in 40 to 2,400 gal of additional leakage, based on the range of historic leakage rate data. A two-week response time may result in 600 to 34,000 gal of additional leakage. Thus, for the response times considered, the total leakage that may occur before and after detection may range from about 6,000 to $54,000 \mathrm{gal}$ with currently available technology, and from about 1,000 to $47,000 \mathrm{gal}$ with the unproven ERT technology. Leakage of these levels may have significant impacts on risk in certain tanks. Only a fraction of the tanks are expected to leak during sluicing, however, and a high percentage of the leaking tanks are expected to leak at upper elevations on the tank wall where the amount of leakage will be minimized.

\subsubsection{Criterion Recommendation}

The range and maximum levels of leakage that may occur before and after leakage detection are high. However, the probability of a large amount of leakage is low due to the expected benefits of core sluicing, the low incidence of large amounts of leakage in the past, and the use of leakage detection technology. The use of ERT technology, if and when it is proven, may reduce the magnitude of leakage by providing earlier detection when the tank is being filled to establish base sluicing conditions. The effectiveness of salt well pumping as a leakage response action should be better quantified. 
WHC-SD-WM-ES-392 REV. 0

\subsection{CRITERION 15 - LEAKAGE MITIGATION TECHNOLOGY}

Determine which leakage mitigation technologies are viable and how much impact will they have on reducing leakage.

\subsubsection{Importance of Criterion}

Various methods of mitigating leakage are available and have potential to limit the risks associated with leakage. These methods include using subsurface barriers, sluicing with liquids containing entrained sludge particles, sluicing the core area of the tank first, and using salt well pumping to reduce the heal of liquid in the leaking tank. Foster Wheeler evaluated subsurface barrier technologies as a means of containing leakage from tanks, and concluded that all of the technologies evaluated would pose significant technical and worker safety risks and exhibit low cost-effectiveness in general-use applications. Foster Wheeler also proposed limiting the sludge settling time in the sluicing receiver tank in order to entrain the slowest settling sludge particles in the sluicing stream as a means of plugging small leaks with particles. Sluicing the core area of the tank first in order to retain a layer of waste as a seal over leaks that may exist in the wall of the tank was proposed in the draft Single-Shell Tank Closure Work Plan (WHC 1994). Salt-well pumping is a proven technology for minimizing the level of drainable liquid in a tank, and could be used following detection of leakage.

\subsubsection{Criterion Recommendations}

Cost-effective leakage mitigation technologies should be used to limit leakage to the minimum practicable achievable level. Subsurface barriers do not appear to be cost-effective in general-use applications, but may prove to be useful for limiting leakage from tanks that have experienced high leakage rates. Sluicing the core of the tank waste first is recommended as part of the tank waste retrieval baseline. Using entrained fine sludge particles in the sluicing stream may be effective, especially during the later stages of sluicing when most of the easily suspended finer particles have been removed from the tank, leaving coarser, highly permeable sludge to be removed. Salt-well pumping should be used where feasible following detection of leakage. 
WHC-SD-WM-ES-392 REV. 0

\subsection{CRITERION 16 - INDIVIDUAL TANK CHARACTERISTICS}

Consider the design and physical characteristics of individual tanks when defining allowable leakage.

\subsubsection{Importance of Criterion}

Hanford Site tanks vary significantly in design, physical integrity, and characteristics of the waste they contain. The capacities of the tanks range from 50,000 to $1,000,000 \mathrm{gal}$. Some tanks are highly congested with failed pumps, sluicers, air-lift circulators, and instrumentation; the head space in other tanks is highly restricted. Some tanks have several available pump and sluicer pits, whereas some have none. Some tank farms are cluttered with essential service and monitoring equipment. The tanks contain varying quantities of waste exhibiting different retrieval difficulties. Some tanks have leaked in the past, and some contain potentially flammable and explosive materials. All of these factors may restrict the ability to use specific waste retrieval, leakage detection, and leakage mitigation technologies in individual tanks or tank farms. These factors may also impact the rate of sluicing and head of sluicing liquid in the tanks. Thus, design and operating latitudes and constraints are likely to be imposed for individual tanks to ensure safe and efficient retrieval operations. These latitudes and constraints may directly impact the allowable leakage from those tanks.

\subsubsection{Criterion Recommendation}

Allowable leakage for individual tanks should be based in part on estimates of the probabilities and amounts of leakage derived from evaluation of (1) the specific characteristics of the tanks and (2) the retrieval, leakage detection, and leakage mitigation technologies likely to be best suited to individual tank characteristics. This will provide a basis for a balanced, cost-effective approach to the design and operation of waste retrieval and LDMM equipment. 


\subsection{CRITERION 17 - EXCEEDANCE OF ALLOWABLE LEAKAGE VALUES}

Determine the consequences of exceeding an allowable leakage value.

\subsubsection{Importance of Criterion}

Exceeding an allowable leakage value can be accommodated by reducing the allowable leakage values of other aligned waste sources. It can also be accommodated by increasing the tank's cleanout objective from $99 \%$ to $99.5 \%$, for example, or allocating higher cleanup objectives among several aligned tanks.

\subsubsection{Criterion Recommendation}

Authority should be granted to exceed an allowable leakage value up to a predetermined ceiling. Retrieval operations should be allowed to continue to the ceiling level. An exceedance of the allowable leakage value up to the ceiling level should be accommodated by modifying the cleanup objectives of other aligned sources. Similarly, achieving a degree of leakage below the allowable leakage value can increase flexibility, e.g., by enabling higher allowable leakage values in other aligned tanks. Immediate cessation of sluicing operations should be required when a leakage ceiling is exceeded. Reevaluation of waste retrieval plans should then occur. Revised plans may dictate the use of dry retrieval methods to prevent any additional leakage, or razing the tanks and exhuming contaminated debris and soils. 
WHC-SD-WM-ES-392 REV. 0

\subsection{CRITERION 18 - EXCEEDANCE OF LEAKAGE CEILINGS}

Establish whether sluicing should be allowed when there is a likelihood of exceeding a leakage ceiling.

\subsubsection{Importance of Criterion}

Previous analyses conducted by Boomer et al. (1994) and Foster Wheeler indicated that alternate tank waste retrieval options, including dry and semi-dry retrieval options pose high costs and worker risks. Very high costs and worker risks were attributed to tank razing and debris/soil excavation and treatment.

\subsubsection{Criterion Recommendation}

Plans should be made to maximize use of sluicing with the ultimate objective of achieving compliance with the requirements of the closure plan. Dry or semi-dry retrieval should be planned as the first contingency if leakage ceilings are exceeded. Razing the tanks and excavating the contaminated debris and soil should be considered the last resort. 
WHC-SD-WM-ES-392 REV. 0

\subsection{CRITERION 19 - ABSOLUTE LIMIT ON ALLOWABLE LEAKAGE}

Establish whether an absolute limit should be imposed on the amount of leakage allowable to ensure protection of the groundwater.

\subsubsection{Importance of Criterion}

A very high level of leakage could conceivably penetrate to and contaminate the groundwater. The highly drained nature of Hanford Site soils creates a sponge-like effect that would significantly retard the flow of leaked liquid waste to the water table. Preliminary calculations performed by Foster Wheeler indicate that at least 200,000 gal of leakage below individual tanks would be bound in the soil well above the water table. The water would travel vertically toward the water table at sufficiently low rates to allow excavation of the contaminated soil, if necessary. Another evaluation performed by Foster Wheeler indicated that up to $480,000 \mathrm{gal}$ of liquid could leak from a Tank 241-A-101, including the water added to the tank to create base conditions before initiating sluicing. A maximum of $140,000 \mathrm{gal}$ could leak in the typical case based on average drainable liquid data and volumes of water required to submerge the head of the slurry removal pump. Thus, maximum levels of leakage from individual tanks would not pose environmental threats in most cases if excavation and treatment of the soil, or a similarly effective technology is planned as a mitigating action.

\subsubsection{Criterion Recommendation}

Individual tank conditions and soil conditions at the tank farm should be used to model the spread of the maximum potential leakage to verify that the leakage can be dealt with within the limits of feasibility of available mitigation technologies. The probability of maximum leakage should also be considered before imposing an absolute limit on allowable leakage. 
WHC-SD-WM-ES-392 REV. 0

\subsection{EXAMPLE PROCESS FOR DERIVING ALLOWABLE LEAKAGE VALUES}

Criteria established in Section 3 were used, with a few noted exceptions, to derive allowable leakage values for a hypothetical tank farm containing six tanks. The process used to develop preliminary allowable leakage values is described in the order of the criteria previously presented. The process used to adjust allowable leakage values during a sequenced hypothetical cleanup of the six tanks is also described.

\subsection{PRELIMINARY ALLOWABLE LEAKAGE VALUES}

The preliminary allowable leakage values are calculated for this hypothetical case to support retrieval planning decisions and establish the operational leakage limit for the first tank retrieved. The final criteria used to establish the preliminary allowable leakage values are shown below.

- Criterion 1 - The maximally exposed onsite residential farmer scenario was used as the controlling risk basis.

- Criterion 2 - The Multimedia Environmental Pollutant Assessment System was used to model the risk scenario. Typical Hanford Site environmental modeling conditions and input data were used. The model conditions and input data are similar to those used in the draft TWRS-EIS.

- $\quad$ Criterion 3 - The point of compliance was assumed to be immediately downgradient of the tank farm.

- Criterion 4 - Compliance risks were modeled over a 30,000-year period.

- $\quad$ Criterion 5 - The primary COCs evaluated were ${ }^{99} \mathrm{Tc},{ }^{129} \mathrm{I},{ }^{14} \mathrm{C}$, uranium, and nitrate.

- Criterion 6 - The flux from the tank farm was assumed to be released into a vadose zone cell with surface dimensions equal to that of the tank farm.

- Criterion 7 - The allowable incremental lifetime cancer risk was assumed to be $10^{-4}$ in one case and $10^{-5}$ in a second case.

- $\quad$ Criterion 8 - The risk impacts of past leakage and waste contaminated concrete were considered in addition to the risk impacts associated with residual waste in the tank and new leakage.

- Criterion 9 - The concentrations of COCs were based on the assumptions made in Functions and Requirements for Hanford Single Shell Tank Leakage Detection and Monitoring (Cruse et al. 1995). These assumptions are somewhat conservative compared to the recommended approach. 
- Criterion 10 - The selected closure approach was backfilling the tanks with gravel following nominal retrieval of $99 \%$ of the waste and capping with a Hanford Barrier.

- Criterion 11 - The volume of assumed leakage in the tank farm in the past was $285,000 \mathrm{gal}$ based on historical data.

- Criterion 12 - No other tank farms or waste sites that contribute COCs were assumed aligned with the hypothetical tank farm. Carcinogenic risk limits assumed for the single tank farm were $10^{-4}$ and $10^{-5}$ as in Criterion 7 .

- $\quad$ Criterion 13 - There was no need to divide risk limits between other aligned farms and contributing waste sites.

- Criteria 14 and 15 - Currently available leakage detection and mitigation technology were assumed to be able to limit total new leakage in the tank farm to a maximum of $60,000 \mathrm{gal}$.

- Criterion 16 - The design and physical characteristics of the tanks in the farm were assumed not to restrict the use of sluicing and the application of currently available leakage detection and mitigation technologies.

- Criterion 17 - Modeling showed that the planned actions for the tank farm could not satisfy the $10^{-5}$ risk limit. More efficient sluicing would be required to accommodate a reasonable level of leakage and comply with the $10^{-5}$ risk limit. However, the planned actions would satisfy the $10^{-4}$ risk limit.

- Criterion 18 - Dry and semi-dry retrieval methods were planned as possible contingencies.

- Criterion 19 - The tank and soil conditions indicated that the maximum potential leakage would penetrate to a depth that could be accessed using current excavation technology. Thus, no absolute limit on leakage was established.

Based on application of the criteria, the preliminary allowable leakage values shown in Table 4-1 were determined. As can be seen, the soil capacity (Tier 1) exceeds the maximum potential leak (Tier 2) in all cases. Additionally, the preliminary allowable leakage values (Tier 3) are all large enough to be above the leakage detection limit of 6,000 to $20,000 \mathrm{gal}$. On the basis of this planning exercise, it was assumed that remediation of the tank farm using sluicing was authorized and to be conducted under the $10^{-4}$ risk limit. 
Table 4-1. Hypothetical Preliminary Allowable Leakage Criteria.

\begin{tabular}{|c|c|c|c|}
\hline Tank & Tier 1 (gal) & Tier 2 (gal) & Tier 3 (gal) \\
\hline \hline 1 & 200,000 & 180,000 & 46,000 \\
\hline 2 & 200,000 & 77,000 & 38,000 \\
\hline 3 & 200,000 & 90,000 & 66,000 \\
\hline 4 & 200,000 & 68,000 & 38,000 \\
\hline 5 & 200,000 & 67,000 & 100,000 \\
\hline 6 & 200,000 & 74,000 & 80,000 \\
\hline
\end{tabular}

\subsection{ADJUSTED ALLOWABLE LEAKAGE VALUES}

The following is a hypothetical example of how the preliminary allowable leakage values would be applied and updated as retrieval of each of the tanks in the tank farm was concluded.

When the first tank was sluiced, the operations personnel were granted an operational leakage limit of $46,000 \mathrm{gal}$ (the Tier 3 allowable leakage value). During retrieval of this tank no leakage was detected and the $99 \%$ retrieval objective for the tank was met. A small level of leakage $(3,000 \mathrm{gal})$ was attributed to the tank, however, as a function of the probability for and volume of the average nondetectable leakage. The difference between the allowed volume of leakage and the assumed nondetectable leakage was converted to a risk credit. This risk credit was evenly apportioned to the remaining tanks in terms of additional allowable leakage volume. An updated operational leakage limit was established for the second tank of 45,000 gal based on this additional risk credit. No leakage was detected when the second tank was successfully sluiced. The same risk credit was again distributed to the remaining tanks in terms of increased allowable leakage volumes.

The third tank was also sluiced without detectable leakage, but only $98 \%$ of the waste was retrieved rather than the goal of $99 \%$. Because no leakage was observed, the tank farm was debited for the risk associated with the assumed 3,000 gal nondetectable leak. The risk associated with the shortfall in waste retrieval was then subtracted from the remaining risk allowance for leakage from the three tanks that had not yet been sluiced. The difference was evenly divided between the three tanks. This resulted in reducing the original allowable leakage values assigned to the tanks to a small fraction of their original levels.

The fourth and fifth tanks were sluiced, and although retrieval goals were met, the tanks leaked above their reduced allowable leakage values, consuming the leakage risk allocation associated with leakage from the sixth tank. The sixth tank had been scheduled as the last tank in the farm to be retrieved because the integrity of the tank was suspect. Had sufficient leakage and/or residual waste risk credit been built up during cleanout of the first five tanks, the sixth tank would have been sluiced. Thus the sixth tank was cleaned out instead using a dry retrieval method. The tank farm was then closed by backfilling each tank 
WHC-SD-WM-ES-392 REV. 0

with gravel and capping the farm with a Hanford Barrier to achieve a predicted cumulative ICLR of $9 \times 19^{-5}$. 


\subsection{SUMMARY OF CRITERIA RECOMMENDATIONS REQUIRING APPROVAL}

A summary of the allowable leakage criteria recommendations requiring approval is provided in Table 5-1.

Table 5-1. Summary of Criteria Recommendations.

\begin{tabular}{|c|c|c|}
\hline Number & $\begin{array}{l}\text { Allowable Leakage } \\
\text { Criteria }\end{array}$ & Recommendations \\
\hline 1 & Controlling Risk Scenario & $\begin{array}{l}\text { - Maximally Exposed Individual } \\
\text { - Groundwater use pathway } \\
\text { - Onsite farmer } \\
\text { - Consistent with TWRS-EIS }\end{array}$ \\
\hline 2 & Risk Models and Data & $\begin{array}{l}\text { - One-dimensional release algorithms and transport } \\
\text { models } \\
\text { - Consistent with TWRS-EIS }\end{array}$ \\
\hline 3 & Point of Compliance & $\begin{array}{l}\text { - Several compliance points for sensitivity } \\
\text { - Based on future land use planning }\end{array}$ \\
\hline 4 & Duration of Compliance & - Establish effectiveness of Hanford Surface Barrier \\
\hline 5 & Constituents of Concern & - ${ }^{99} \mathrm{Tc},{ }^{129} \mathrm{I},{ }^{14} \mathrm{C}$, uranium, and nitrate \\
\hline 6 & $\begin{array}{l}\text { Vadose Zone Flux } \\
\text { Distribution }\end{array}$ & - Consistent with points of compliance \\
\hline 7 & Allowable Risk & $\begin{array}{l}\text { - } 10^{-4} \text { or } 10^{-5} \text { incremental lifetime cancer risk } \\
\text { - Hazard index of } 1.0\end{array}$ \\
\hline 8 & Tank Sources of Risk & $\begin{array}{l}\text { - Cumulative risk impacts of all tank sources should } \\
\text { be considered }\end{array}$ \\
\hline 9 & Leakage Concentrations & $\begin{array}{l}\text { - Use average relative concentrations of COCs in } \\
\text { sluicing liquid and in sludge }\end{array}$ \\
\hline 10 & $\begin{array}{l}\text { Acceptable Closure } \\
\text { Options }\end{array}$ & $\begin{array}{l}\text { Assume the tanks are filled with gravel or grout and } \\
\text { covered with a Hanford Barrier following waste } \\
\text { retrieval as the preferred option } \\
\text { - Plan for tank razing and soil excavation or in situ } \\
\text { soil washing as contingency }\end{array}$ \\
\hline 11 & Leakage Volumes & $\begin{array}{l}\text { - Initially assume the historical average of } 11,000 \mathrm{gal} \\
\text { - Perform a more rigorous analysis }\end{array}$ \\
\hline 12 & Aligned Waste Sources & $\begin{array}{l}\text { Exclude unimportant sources that will not be capped } \\
\text { - All other aligned waste sources should be considered } \\
\text { in calculation of cumulative risk }\end{array}$ \\
\hline
\end{tabular}


WHC-SD-WM-ES-392 REV. 0

\begin{tabular}{|c|l|l|}
\hline Number & \multicolumn{1}{|c|}{$\begin{array}{c}\text { Allowable Leakage } \\
\text { Criteria }\end{array}$} & \multicolumn{1}{c|}{ Recommendations } \\
\hline \hline 13 & Risk Apportionment & $\begin{array}{l}\text { Don't cover low-risk sites (such as some cribs and } \\
\text { trenches) where safe groundwater conditions can be } \\
\text { ensured } \\
\text { Evaluate risk reduction levels based on cost- } \\
\text { effectiveness of feasible options for entire system }\end{array}$ \\
\hline 14 & $\begin{array}{l}\text { Leakage Detection } \\
\text { Technology }\end{array}$ & $\begin{array}{l}\text { The current baseline detection technology is adequate } \\
\text { to support retrieval } \\
\text { The use of ERT technology, if proven, should } \\
\text { provide earlier leak detection }\end{array}$ \\
\hline 15 & $\begin{array}{l}\text { Leakage Mitigation } \\
\text { Technology }\end{array}$ & $\begin{array}{l}\text { Sluice the core of the tank waste first } \\
\text { Salt-well pumping should be used where practical } \\
\text { following leak detection }\end{array}$ \\
\hline 16 & $\begin{array}{l}\text { Use of entrained fine sludge particles may prove } \\
\text { effective } \\
\text { Subsurface barriers generally are not cost-effective }\end{array}$ \\
\hline 17 & $\begin{array}{l}\text { Individual Tank } \\
\text { Characteristics }\end{array}$ & $\begin{array}{l}\text { Base allowable leakage in part on tank design, } \\
\text { physical integrity, and waste characteristics }\end{array}$ \\
\hline 18 & $\begin{array}{l}\text { Exceedance of Allowable } \\
\text { Exceedance of Leakage }\end{array}$ & $\begin{array}{l}\text { Authority should be granted to exceed an allowable } \\
\text { leakage value up to a predetermined cap }\end{array}$ \\
\hline 19 & $\begin{array}{l}\text { Maximize use of sluicing } \\
\text { Plan as a first contingency, use of dry or semi-dry } \\
\text { retrieval } \\
\text { Tank razing and soil excavation should be a last } \\
\text { resort }\end{array}$ \\
\hline Absolute Limit on & $\begin{array}{l}\text { Use tank-specific models to verify that the maximum } \\
\text { potential leakage (Tier 2) can be dealt with within } \\
\text { the limits of available mitigation technology }\end{array}$ \\
\hline
\end{tabular}




\subsection{REFERENCES}

Boomer, K.D., S.K. Baker, A.L. Boldt, J.D. Galbraith, J.S. Garfield, C.E. Golberg,

B.A. Higley, L.J. Johnson, M.J. Kupfer, R.M. Marusich, R.J. Parazin, A.N. Praga, G.W. Reddick, J.A. Reddick, E.J. Slaathaug, L.M. Swanson, T.L. Waldo, and C.E. Worcester, 1994, Tank Waste Technical Options, WHC-EP-0616, Rev. 1, Westinghouse Hanford Company, Richland, Washington.

Cruse, J.M., D.F. Iwatate, K.S. Tollefson, R.L. Treat, T.L. Trenkler, R.E. Lewis, 1995, Functions and Requirements for Hanford Single-Shell Tank Leakage Detection and Monitoring, WHC-SD-WM-FRD-021, Rev. 0, Westinghouse Hanford Company, Richland, Washington.

Hanlon, B.M., 1995, Waste Status Summary Report for the Month Ending October 31, 1995, WHC-EP-0182-91, Westinghouse Hanford Company, Richland, Washington.

WHC, 1994, Single-Shell Tank Closure Work Plan, DOE/RL-89-16, Rev. A, Westinghouse Hanford Company, Richland, Washington. 
WHC-SD-WM-ES-392 REV. 0

This page intentionally left blank. 


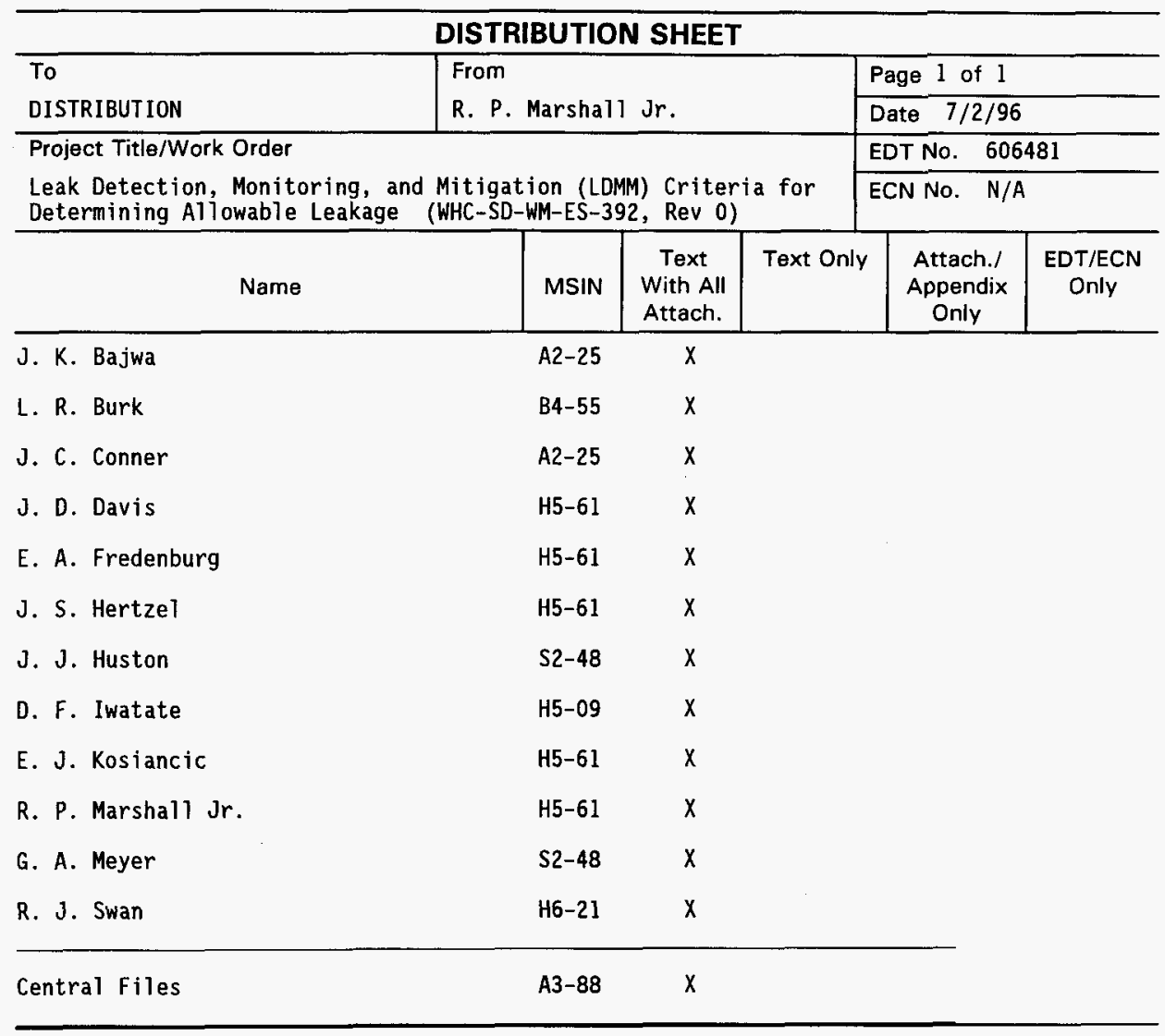

